ORNL/ LTR-2016/ 683

\title{
Preliminary Engineering Report for the Use of Peracetic Acid at the Oak Ridge National Laboratory Sewage Treatment Plant
}

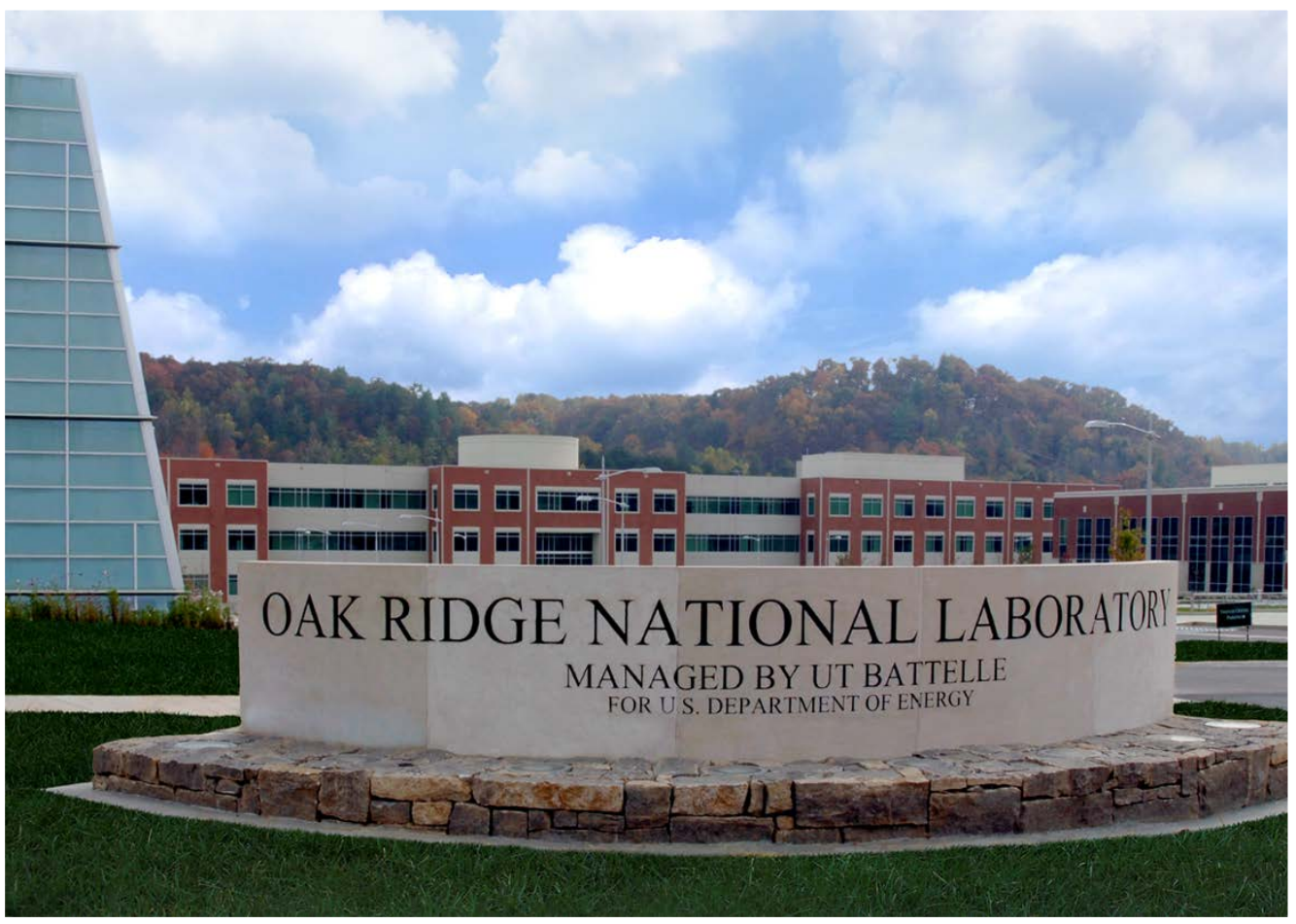

Approved for public release. Distribution is unlimited.

Paul A. Taylor

March 2017 


\section{DOCUMENT AVAILABILITY}

Reports produced after January 1, 1996, are generally available free via US Department of Energy (DOE) SciTech Connect.

Website http://www.osti.gov/scitech/

Reports produced before January 1, 1996, may be purchased by members of the public from the following source:

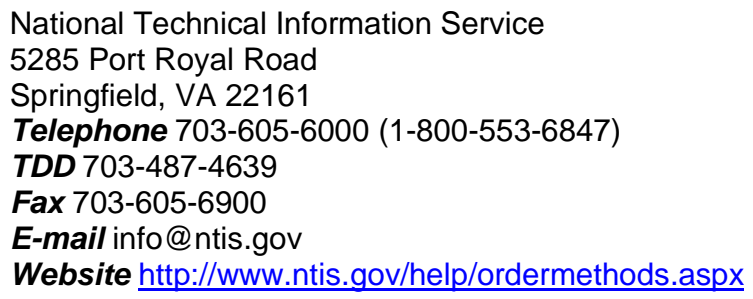

Reports are available to DOE employees, DOE contractors, Energy Technology Data Exchange representatives, and International Nuclear Information System representatives from the following source:

Office of Scientific and Technical Information

PO Box 62

Oak Ridge, TN 37831

Telephone 865-576-8401

Fax 865-576-5728

E-mail reports@osti.gov

Website http://www.osti.gov/contact.html

This report was prepared as an account of work sponsored by an agency of the United States Government. Neither the United States Government nor any agency thereof, nor any of their employees, makes any warranty, express or implied, or assumes any legal liability or responsibility for the accuracy, completeness, or usefulness of any information, apparatus, product, or process disclosed, or represents that its use would not infringe privately owned rights. Reference herein to any specific commercial product, process, or service by trade name, trademark, manufacturer, or otherwise, does not necessarily constitute or imply its endorsement, recommendation, or favoring by the United States Government or any agency thereof. The views and opinions of authors expressed herein do not necessarily state or reflect those of the United States Government or any agency thereof. 
Nuclear Security \& I sotope Technology

\title{
A Preliminary Engineering Report for the Use of Peracetic Acid at the Oak Ridge National Laboratory Sewage Treatment Plant
}

Paul A. Taylor, ORNL

March 2017

\author{
Prepared by \\ OAK RIDGE NATIONAL LABORATORY \\ Oak Ridge, Tennessee 37831-6283 \\ Managed by \\ UT-BATTELLE, LLC \\ for the \\ US DEPARTMENT OF ENERGY \\ under contract DE-AC05-00OR22725
}




\title{
Preliminary Engineering Report for the use of Peracetic Acid (PAA) \\ at the Oak Ridge National Laboratory (ORNL) Sewage Treatment Plant (STP)
}

\author{
Paul Taylor, 2/2/2017, Oak Ridge National Laboratory
}

\section{Background}

The disinfection of wastewater effluent is necessary to ensure the inactivation of pathogenic organisms that are present in the untreated wastewater. These pathogenic organisms must be neutralized to prevent the spread of water borne diseases within the receiving stream. The most common form of disinfection is achieved by adding a chemical oxidant to the clarified or filtered effluent, although UV disinfection has found success as well.

Disinfection at ORNL's STP was originally carried out through the addition of chlorine, which requires dechlorination prior to discharge to the receiving stream. Because of occasional failures with the dechlorination system, toxic concentrations of chlorine were infrequently released to the creek. Because of these issues and concerns over the formation of toxic chlorinated byproducts (e.g., trihalomethanes), the decision was made to switch to ozone disinfection, which has been in place for about 20 years.

Ozone disinfection is an energy intensive method that is also maintenance intensive to keep the systems operating properly. Ozone disinfection also requires cooling of the equipment, which is done using oncethrough cooling water at ORNL. In addition to the maintenance burdens associated with ozone, there have been safety concerns raised about worker exposure to the highly toxic ozone gas. Ozone collects in the head space of the contact chamber, at concentrations above what can be vented to the atmosphere. Ozone destruction equipment is used to treat the off-gas and convert the residual back to oxygen. An exhaust fan draws the off-gas from the contact chamber through an ozone destructor. It contains a catalyst that decomposes the ozone to oxygen, reducing the ozone concentration to a level that is safe for venting. Atmospheric monitoring equipment is required at the ozone generation facility to ensure exposure limits are not exceeded for the workers.

\section{Purpose}

The purpose of this report is to identify other disinfection methods to replace the current ozone system and propose a small pilot-scale test. Based on a review of the literature and disinfectants used by other wastewater plants in Tennessee, peracetic acid (PAA) was identified as a leading candidate. This report provides the basis for requesting approval for a pilot-scale study using PAA.

\section{PAA Strategy}

Commercial PAA solutions are a mixture of PAA, acetic acid, hydrogen peroxide, and water. When PAA decomposes in water, hydrogen peroxyl $\left(\mathrm{HO}_{2}\right)$ and hydroxyl $(\mathrm{OH})$ radicals are formed, which are very strong oxidizers. These free radicals interact with pathogens through protoplasmic oxidation which results in the destruction of the cell walls and intercellular enzymes. The decomposition of the PAA to meet the oxidant demand of a wastewater occurs rapidly, which results in the rapid dissipation of PAA residuals if dosage rates are kept at equilibrium with oxidant demand.

The existing contact chamber for the ORNL STP was designed to provide disinfection using chlorine, but was converted to use ozone. The design of the chamber provides sufficient volume for an average of 25 minutes retention time at the treatment facility's design flow rate. PAA residuals can be neutralized by adding sodium metabisulfite; however, this is not generally required, due to the low dosages required for 
disinfection and the rapid decay. Ensuring that PAA can effectively meet the disinfection requirements for the ORNL STP without significant impacts to the creek will require additional study. An onsite pilot study will allow DOE to determine the required dosage rates for disinfection, and to measure the residual PAA concentration in the effluent.

Upon completion of the proposed pilot study, DOE will have the information necessary to determine whether PAA is an adequate and economical disinfectant for the STP. Based on the results, design plans and supporting documentation will be finalized and submitted to TDEC for approval to install a permanent PAA system to replace the ozone generators. The existing ozone system will be kept as a backup option.

\section{Water Quality Standards}

TDEC has not at this time developed a maximum contaminant level for PAA. The by-products of PAA decomposition are also non-listed compounds. Because of this, the mandated limitation for feeding PAA for disinfection of the wastewater effluent is to maintain de minimis degradation to the quality of the receiving stream.

The receiving stream for the STP is White Oak Creek (WOC), which has a 7Q10 of 950,000 gallons per day (gpd) at the point of discharge. At a design discharge rate of 300,000 gpd, the dilution factor for the STP discharge into the receiving stream at low flow is $\sim 3$. This presents a moderate amount of dilution but not enough to forgo relatively stringent effluent limitations for disinfectant residuals. Because of the use of ozone, the permit currently does not require the monitoring of disinfectant residuals. Therefore, a safe concentration for PAA residuals needs to be developed.

The use of PAA has been explored for other STP systems in Tennessee. In Lexington the most sensitive aquatic species was green algae, which had an effective concentration $\left(\mathrm{EC}_{50}\right)$ value of $0.18 \mathrm{mg} / \mathrm{L}$ and the no observed effect concentration (NOEC) value was found to be $0.12 \mathrm{mg} / \mathrm{L}$. In Tullahoma the $25 \%$ inhibition concentration $\left(\mathrm{IC}_{25}\right)$ values for Ceriodaphania dubia and Pimephales promelas were 0.38 and $0.75 \mathrm{mg} / \mathrm{L}$, respectively.

Potential indicators of stream quality degradation would be impacts to the benthic communities near the outfall. However, in consideration of the design of the contact chamber and the dilution factor of the receiving stream it is unlikely that the use of PAA at the ORNL STP will have an effect on the water quality of the receiving stream. The proposed pilot-scale test will determine the concentration of PAA required to disinfect the STP effluent, and will provide disinfected effluent for toxicity testing using $C$. daphnia and P. promelas

\section{Pilot Study}

The pilot-scale study will use a side stream of effluent from the ORNL STP, collected after filtration but prior to ozone addition. The side stream $(\sim 1 \mathrm{~L} / \mathrm{min})$ will be pumped to a small contact chamber $(\sim 25 \mathrm{~L})$, and a diluted stock solution of PAA will be pumped into the side stream just before it enters the contact chamber. A flow diagram of the pilot-scale system is shown in Figure 1. Effluent from the pilot-scale system will be discharged into the STP contact chamber. A sample of Peragreen 22WW PAA solution was obtained from Enviro Tech Chemical Services, Inc. (Modesto, CA), which contains 21-23\% PAA, 4.2-5.2\% hydrogen peroxide and 40-50\% acetic acid. The 22WW PAA solution will be diluted 1:100 in deionized water to prepare the stock solution ( $2200 \mathrm{mg} / \mathrm{L}$ PAA). Pumping $0.46 \mathrm{~mL} / \mathrm{min}$ of the stock solution into the effluent side stream will give an initial concentration of $1.0 \mathrm{mg} / \mathrm{L} \mathrm{PAA}$. The 
concentration of PAA will be adjusted to determine the range of concentrations that provide good disinfection with low residual PAA concentration in the effluent from the pilot-scale contact chamber. PAA solutions from other suppliers may also be tested.

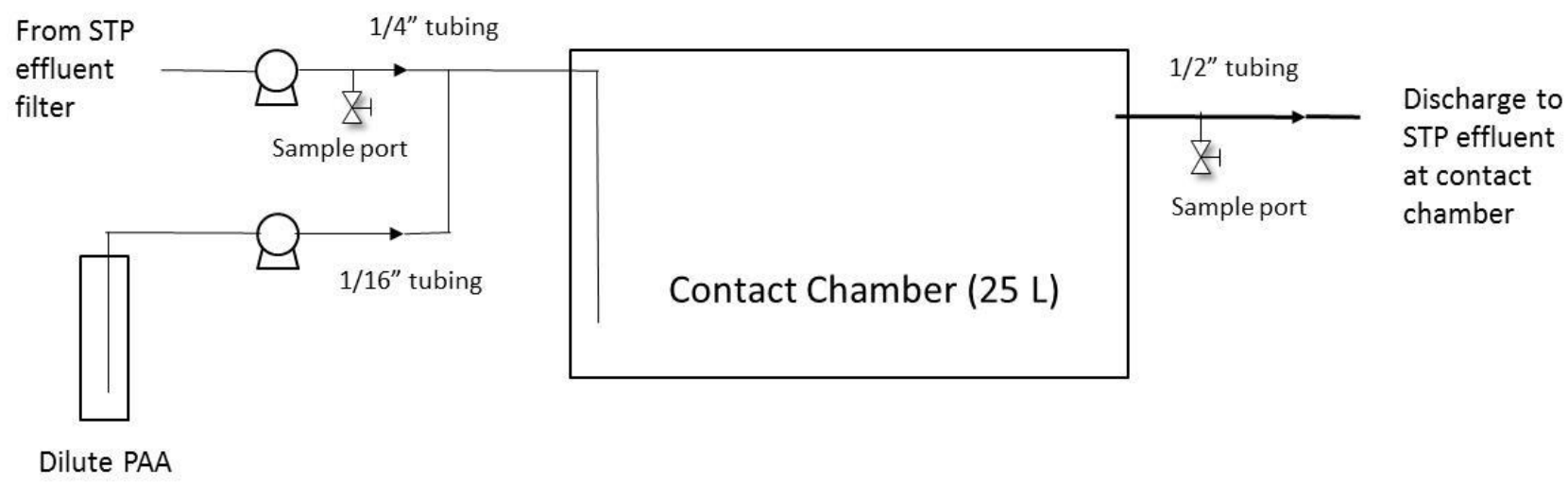

Fig. 1. Flow diagram of pilot-scale system

The PAA and hydrogen peroxide $\left(\mathrm{H}_{2} \mathrm{O}_{2}\right)$ concentrations will be measured once a day using a Colorimeter and AccuVac DPD (N,N Diethyl-1,4 Phenylenediamine Sulfate) vials, both from Hach Company (Loveland, CO). The analyses will follow the procedure in Application Note - Determination of Peracetic Acid and Hydrogen Peroxide in Water from Hach. For PAA analysis, each sample is analyzed using the standard method for total chlorine, and then this result is multiplied by 1.07 to calculate the concentration of PAA. $\mathrm{H}_{2} \mathrm{O}_{2}$ does not react directly with the DPD reagent; however, adding 3 drops each of $20 \%$ potassium iodide solution and $4 \%$ ammonium molybdate solution and letting the solution react for 6 minutes converts the hydrogen peroxide to an equal molar concentration of iodine, which does react with DPD. The measured concentration is the combined amount of PAA and hydrogen peroxide. Subtracting the measured PAA concentration from the combined value and multiplying by 0.478 gives the $\mathrm{H}_{2} \mathrm{O}_{2}$ concentration. A study at the Lexington, TN Wastewater Treatment Facility (Brey Funkhouser and Joseph Donabed, Decay Study For Peroxyacetic Acid (BioSide HS 15\%) in Lexington Wastewater Effluent, March 30, 2015) showed that PAA concentration in their effluent decayed from 20 ppm to 10.5 ppm in 130 minutes, while the $\mathrm{H}_{2} \mathrm{O}_{2}$ only decayed from $30.5 \mathrm{ppm}$ to $27.8 \mathrm{ppm}$. Because of the large initial concentrations of PAA and $\mathrm{H}_{2} \mathrm{O}_{2}$, any materials in the effluent that could be oxidized would have been rapidly consumed, leaving only natural decay of the PAA and $\mathrm{H}_{2} \mathrm{O}_{2}$, to reduce the concentrations. For the ORNL pilot-scale test, the difference in initial and final (discharge from pilot-scale contact chamber) concentrations of PAA and $\mathrm{H}_{2} \mathrm{O}_{2}$ will show the decay rate at low initial concentrations. Because of the large dilution of the pilot-scale effluent into the STP discharge (at least 300:1), any PAA and $\mathrm{H}_{2} \mathrm{O}_{2}$ left in the pilot-scale effluent will immediately be diluted to vanishingly low concentrations before entering White Oak Creek.

The E. coli concentration in the effluent from the pilot-scale system will be measured each workday using EPA Method 1603: Escherichia coli (E. coli) in Water by Membrane Filtration Using Modified Membrane- Thermotolerant Escherichia coli Agar (modified mTEC). Method 1603 provides a direct count of E. coli in ambient water or wastewater based on the development of colonies that grow on the surface of a membrane filter. A sample is filtered through the membrane, which retains the bacteria. After filtration, the membrane is placed on a selective and differential medium (modified mTEC agar) incubated at $35^{\circ} \mathrm{C} \pm 0.5^{\circ} \mathrm{C}$ for $2 \pm 0.5$ hours to resuscitate injured or stressed bacteria, and then incubated at $44.5^{\circ} \mathrm{C} \pm 0.2^{\circ} \mathrm{C}$ for $22 \pm 2$ hours. The target colonies on modified mTEC agar are red or magenta in color after the incubation period. 
Chemical biological oxygen demand (CBOD) will be periodically measured in the influent and effluent of the pilot-scale system to determine the impact of the acetic acid in the PAA solution on the CBOD of the effluent.

A 7-day whole effluent toxicity (WET) test will be conducted on the effluent from the pilot-scale system using $C$. daphnia and $P$. promelas. The WET test will be conducted after the PAA dosage has been optimized. The pilot-scale test will be conducted for at least 40 days.

\section{Full-Scale Implementation Plan}

It is expected that the pilot-scale test will provide sufficient data to determine the dosage of PAA to add to the ORNL STP effluent that would provide adequate disinfection of the effluent without requiring neutralization of the PAA and $\mathrm{H}_{2} \mathrm{O}_{2}$. Based on these pilot-scale results DOE would then submit an Engineering Report that would describe the permanent installation/operation of the PAA disinfecting unit and request an NPDES permit modification to allow implementation of PAA disinfection with a compliance schedule that would include instream bioassessment upstream and downstream (near field and far field) of the effluent discharge point (Outfall X01). 